\title{
KINERJA SUMBER DAYA APARATUR \\ MELALUI PENERAPAN E-GOVERNMENT
}

Oleh

\author{
Eem Nurnawati
}

Institut Pemerintahan Dalam Negeri

eemnurnawati2@gmail.com

\begin{abstract}
G overnment has applied e-Government policy through Instruksi Presiden Nomor 3 Tahun 2003.
\end{abstract}

This policy purpose is to raise efficacy, effectivity, transparence, and accountability of governing practice in order to achieve good and to improve public service. One of expectancies coming from e-Government implementation is the improvement of government official performance.

This study examines any e-Government implementation effect to apparatus performance improvement. Study was held by descriptive qualitative method. Datas were collected through desk research and were qualitatively analyzed.

Based on study of several found researchers, it was found that e-Government implementation has effects to apparatus performance. This effect is significant on working quantity dimention and time discipline dimention. On the other hand e-Government implementation has not yet effected on work quality dimention. This finding signifies necessity of apparatus competence developing effort on information technology and communication mastery and use, as essential instrument in e-government implementation.

Keywords: e-government implementation, apparatus performance

Abstrak
D emerintah telah menetapkan kebijakan e-Government melalui Instruksi Presiden Nomor
3 Tahun

2003. Kebijakan tersebut ditujukan untuk meningkatkan efisiensi, efektivitas, transparansi dan akuntabilitas penyelenggaraan pemerintahan guna menyelenggarakan pemerintahan yang baik (good governance) dan meningkatkan layanan publik. Harapan yang muncul dari implementasi e-Government salah satunya adalah meningkatnya kinerja aparatur pemerintahan.

Kajian ini mengupas perihal ada tidaknya pengaruh implementasi e-Government terhadap peningkatan kinerja aparatur. Pengkajian dilakukan dengan menggunakan metode deskriptif kualitatif. Data-data dikumpulkan melalui teknik desk research dan dianalisis secara kualitatif.

Berdasarkan kajian terhadap temuan-temuan beberapa penelitian yang telah dilakukan, diketahui bahwa implementasi e-Government berpengaruh terhadap kinerja aparatur. Pengaruh tersebut paling terasa pada dimensi kuantitas kerja dan dimensi ketepatan waktu. Di sisi lain, diketahui bahwa implementasi e-Government belum berpengaruh terhadap dimensi kualitas kerja. Temuan tersebut menandakan masih perlunya upaya-upaya pengembangan kompetensi aparatur dalam penguasaan dan pemanfaatan teknologi informasi dan komunikasi yang merupakan instrumen utama dalam implementasi e-Government. 
Kata kunci: implementasi e-government, kinerja aparatur

\section{PENDAHULUAN}

ata pemerintahan Indonesia bergerak

$\mathrm{T}$

demikian dinamis pasca bergulirnya era

reformasi. Salah satu fenomena nyata yang berlangsung adalah diimplementasikannya kebijakan otonomi daerah dan desentralisasi pemerintahan. Kebijakan ini terus mengalami pengembangan dan menjadikan kewenangan sekaligus tanggung jawab Pemerintah Daerah semakin besar untuk memajukan daerahnya serta menyejahterakan masyarakatnya. Besarnya kewenangan dan tanggung jawab tersebut tentu saja harus diiringi semangat mewujudkan good government dan good governance dengan menerapkan birokrasi yang tidak kaku, transparan, serta bebas dari korupsi, kolusi dan nepotisme (KKN).

Kebutuhan terhadap birokrasi yang luwes, dalam arti efektif sekaligus efisien, maka seluruh kegiatan pemerintahan mengalami transformasi yang kerap kali disebut sebagai reformasi birokrasi. Guna mendukung keberhasilan reformasi birokrasi, pemerintah menetapkan Instruksi Presiden Nomor 3 Tahun 2003 tentang Kebijakan dan Strategi Nasional Pengembangan e-Government. Penerapan elektronik government (e-Government) sangat diperlukan dalam penyelenggaraan kegiatan pemerintahan, baik di lembagalembaga pemerintahan tingkat pusat maupun daerah. melalui e-Government, semua kegiatan pemerintahan menggunakan teknologi elektronik sehingga semua pekerjaan semakin mudah dan cepat dilaksanakan serta mudah pula dipantau perkembangannya. Di sisi lain, sumber daya aparatur pemerintah tidak memiliki keleluasaan untuk bertindak seenaknya dalam menjalankan tugas karena semua perilakunya selalu terpantau.

Sistem e-Government yang berbasis penggunaan teknologi informasi dan komunikasi di sektor publik bermanfaat untuk meningkatkan efisiensi, efektivitas, transparansi dan akuntabilitas penyelenggaraan pemerintahan dan untuk menyelenggarakan pemerintahan yang baik (good governance). Sesuai ketentuan dalam Instruksi Presiden Nomor 3 Tahun 2003, sistem e-Government diinstruksikan untuk diterapkan di seluruh entitas pemerintahan.

Meskipun mempunyai berbagai keunggulan, sistem e-Government tidak terlepas dari masalah dalam implementasinya. Setidaknya ada tiga permasalahan pokok yang timbul dalam penerapan e-Government, yaitu infrastruktur, kepemimpinan, dan budaya (Azis, 2008) seperti tampak pada Gambar 1. 
dipergunakan dalam e-government system.

c. Keengganan berbagi data dan informasi, agar terintegrasi secara nasional di seluruh lembaga penyedia layanan publik.

\section{Aspek Kepemimpinan}

a. Terjadi konflik kepentingan di tingkat pemerintah pusat dan daerah.

b. Peraturan yang belum tersosialisasikan dan penerapannya belum merata.

c. Pengalokasian anggaran untuk pembangunan infrastruktur pelayanan publik yang memanfaatkan $e$ government system dalam APBN/APBD belum menjadi prioritas.

\section{Aspek Infrastruktur}

a. Adanya ketimpangan digital yang mengakibatkan belum meratanya ketersediaan infrastruktur teknologi informasi dan komunikasi, mengingat secara geografis wilayah Indonesia tersebar di berbagai kepulauan.

b. Ketersediaan infrastruktur untuk pengadaan teknologi informasi dan komunikasi masih terpusat di kota-kota besar. Tenaga ahli di daerah terpencil pun masih sangat jarang, jika tidak mau dikatakan tidak ada.

c. Sistem layanan publik di Indonesia tidak memiliki standar yang baku. Hal ini menghambat pengintegrasian data kependudukan dan dokumen warga negara lainnya secara nasional

Implementasi e-Government tentu saja memerlukan dukungan aparatur yang profesional, berkinerja tinggi, memiliki pelatihan yang memadai, serta berkualitas. Dengan kata lain, usaha setiap lembaga pemerintah untuk mewujudkan prinsipprinsip good governance dalam penyelenggaraan pemerintahan dan pelayanan publik melalui implementasi $e$ -
Government dipengaruhi keberadaan aparatur yang ada. Di sisi lain, implementasi e-Government juga akan mendorong para aparatur untuk meningkatkan kualitasnya agar tidak tertinggal dalam penguasaan teknologi informasi dan komunikasi. Artinya, ada korelasi antara implementasi $e$ Government dengan kualitas serta kinerja aparatur pada lembaga pemerintah. Hal ini selaras dengan salah satu konsep eGovernment, yaitu "government to employees."

Hakikatnya penerapan e-Government antara lain adalah untuk meningkatkan kinerja dan kesejahteraan para aparatur atau karyawan pemerintahan yang bekerja di sejumlah lembaga sebagai pelayan masyarakat (Indrajit, 2006). Pendapat ini memperkuat adanya korelasi antara implementasi e-Government dengan kinerja pelayanan kepada masyarakat yang pada dasarnya memerlukan kinerja aparatur sebagai subjek dari proses penyelenggaraan pemerintahan.

Pendefinisian dan implementasi $e$ Government tidak dapat dipisahkan dari kondisi internal sebuah negara, baik secara makro maupun mikro. Oleh karena itu pemahaman atas e-Government sangat dipengaruhi sejarah, budaya, pendidikan, pandangan politik, dan kondisi ekonomi sebuah negara. Zoeltom (dalam Fransiska dkk., 2014) mendefinisikan e-Government sebagai upaya untuk mengembangkan penyelenggaraan pemerintahan berbasis penggunaan teknologi telekomunikasi dan informasi dalam rangka meningkatkan kualitas layanan publik secara efektif dan efisien. Dalam Instruksi Presiden Nomor 3 Tahun 2003 dijelaskan bahwa yang dimaksud e-Government adalah penyelenggaraan pemerintahan berbasis elektronik

(teknologi informasi dan komunikasi) untuk meningkatkan kinerja pemerintah dalam hubungannya dengan masyarakat, komunitas bisnis, dan kelompok terkait lainnya menuju good governance. 
Berdasarkan Keputusan Menteri Komunikasi dan Informasi Nomor 8 Tahun 2004, objek layanan aplikasi e-Government dapat dibedakan menjadi tiga kategori berrikut ini.

\section{Government to Government}

Aplikasi e-Government kategori ini menangani masalah layanan antarinstansi pemerintah dan atau antarnegara. Berbagai layanan dapat diberikan oleh satu instansi pemerintah kepada instansi pemerintah yang lain sesuai dengan tugas dan fungsi dari instansi tersebut atau sesuai dengan kebutuhan koordinasi antar instansi. Pada umumnya aplikasi government to government bekerja di atas satu jaringan data yang disebut sebagai intranet, yaitu jaringan data yang digunakan untuk keperluan internal instansi pemerintah. Beberapa contoh aplikasi Government to Government adalah:

a. Koordinasi dan konsolidasi anggaran

b. Koordinasi kepegawaian

c. Koordinasi kegiatan bidang ekonomi

d. Koordinasi bidang politik dan keamanan

\section{Government to Citizen}

Aplikasi e-Government kategori ini menangani masalah yang berkaitan dengan layanan kepada masyarakat luas, baik warga negara Indonesia maupun waga negara asing. Beberapa contoh aplikasi Government to Citizen adalah:
a. Kependudukan
b. Keimigrasian
c. Akta nikah

\section{Government to Business}

Aplikasi e-Government kategori ini menangani masalah yang berkaitan dengan layanan pada sektor usaha, baik bentuk usaha komersial nasional maupun asing.
Beberapa contoh aplikasi Government to Business adalah:

a. Pembayaran pajak

b. Perizinan usaha

c. Pengadaan barang dan jasa (eprocurement)

Selain ketiga kategori di atas, Indrajit (2006) menambahkan konsep Government to Employees. Menurutnya, aplikasi $e$ Government juga diperuntukkan untuk meningkatkan kinerja dan kesejahteraan para pegawai atau karyawan pemerintah yang bekerja di sejumlah institusi sebagai pelayan masyarakat.

Instruksi Presiden Nomor 3 Tahun 2003 menyebutkan bahwa upaya pengembangan e-Government diarahkan untuk mencapai empat tujuan, yaitu:

1. Pembentukan jaringan informasi dan transaksi pelayanan publik yang memiliki kualitas dan lingkup yang dapat memuaskan masyarakat luas serta dapat terjangkau di seluruh wilayah Indonesia pada setiap saat, tidak dibatasi oleh sekat waktu dan dengan biaya yang terjangkau oleh masyarakat.

2. Pembentukan hubungan interaktif dengan dunia usaha untuk meningkatkan perkembangan perekonomian nasional dan memperkuat kemampuan menghadapi perubahan dan persaingan perdagangan internasional.

3. Pembentukan mekanisme dan saluran komunikasi dengan lembaga-lembaga negara serta penyediaan fasilitas dialog publik bagi masyarakat agar dapat berpartisipasi dalam perumusan kebijakan negara.

4. Pembentukan sistem manajemen dan proses kerja yang transparan dan efisien serta memperlancar transaksi dan layanan antarlembaga pemerintah dan pemerintah daerah otonom. 
Menurut Indrajit (2005), sebuah negara memutuskan untuk mengimplementasikan $e$ Government karena percaya bahwa dengan melibatkan teknologi informasi dalam kerangka manajemen pemerintahan maka akan memberikan sejumlah manfaat, yaitu:

1. Meningkatkan kualitas pelayanan pemerintah kepada masyarakat dan komunitas negara lainnya.

2. Memperbaiki proses transparansi dan akuntabilitas di kalangan penyelenggara pemerintahan.

3. Mereduksi biaya transaksi, komunikasi, dan interaksi yang terjadi dalam proses pemerintahan.

4. Menciptakan masyarakat berbasis komunitas informasi yang lebih berkualitas.

Setyanto (dalam Handika, 2017) menyebutkan bahwa manfaat atau fungsi dari e-Government adalah sebagai berikut.

1. Meningkatkan pelayanan masyarakat
a. Memberikan jalur pelayanan "satu wajah"
b. Mempercepat proses pelayanan
c. Memberikan informasi yang transparan
d. Standardisasi pelayanan

2. Memperbaiki kinerja pemerintah
a. Pengontrolan kerja yang efektif dari masyarakat
b. Mempercepat pembuatan pelaporan
c. Hasil kerja yang terukur
d. Koordinasi antar instansi

3. Meningkatkan pendapatan
a. Mengundang investor
b. Mengoptimalkan penerimaan
c. Meningkatkan ekspor

Menurut Instruksi Presiden Nomor 3

Tahun 2003, pencapaian tujuan strategis $e$ Government dilaksanakan melalui enam strategi yang berkaitan erat, yaitu:

1. Mengembangkan sistem pelayanan yang andal dan terpercaya, serta terjangkau oleh masyarakat luas.

2. Menata sistem manajemen dan proses kerja pemerintah dan pemerintah daerah otonom secara holistik.

3. Memanfaatkan teknologi informasi secara optimal.

4. Meningkatkan peran serta dunia usaha dan mengembangkan industri telekomunikasi dan teknologi informasi.

5. Mengembangkan kapasitas SDM, baik pada pemerintah maupun pemerintah daerah otonom, disertai dengan meningkatkan e-literacy masyarakat.

6. Melaksanakan pengembangan secara sistematik melalui tahapan-tahapan yang realistis dan terukur.

Sehubungan dengan strategi kelima dapat dinyatakan bahwa SDM, baik sebagai pengembang, pengelola maupun pengguna $e$ Government merupakan faktor yang menentukan bahkan menjadi kunci keberhasilan pelaksanaan dan pengembangan $e$-Government. Untuk itu, perlu upaya peningkatan kapasitas SDM dan penataan dalam pendayagunaannya, dengan perencanaan yang matang dan komprehensif sesuai dengan kebutuhan, serta pelaksanaannya dilakukan secara bertahap dan berkelanjutan. Hal tersebut dilakukan melalui jalur pendidikan formal dan nonformal, maupun pengembangan standar kompetensi yang dibutuhkan dalam pengembangan dan implementasi $e$ Government.

$$
\begin{array}{rr}
\text { Merujuk pada pendapat } \\
\text { Indrajit }
\end{array}
$$


(2005), salah satu faktor penentu yang patut menjadi bahan pertimbangan dalam menentukan tingkat kesiapan sebuah daerah untuk mengimplementasikan e-Government adalah kesiapan aparatur pemerintahan yang akan menjadi "pemain utama" atau subjek dalam inisiatif e-Government. Sumber daya manusia yang bekerja di lembaga pemerintahan sangat penting tingkat kompetensi dan keahlian mereka karena akan sangat memengaruhi performa implementasi $e$-Government.

Kesiapan SDM aparatur dalam implementasi e-Government merupakan tantangan yang dihadapi oleh hampir seluruh entitas pemerintahan. Oleh karena itu, perlu adanya upaya meningkatkan kinerja aparatur dengan mendayagunakan teknologi informasi melalui suatu sistem manajemen informasi yang terintegrasi, cepat dan tanggap. Hal ini diyakini, karena kelancaran penyelenggaraan tugas pemerintahan dan pembangunan tergantung pada kinerja pegawai. Aparatur merupakan unsur pemerintah yang langsung bertugas melayani masyarakat. Kinerja aparatur yang baik dapat mendukung tugas pokok pengembangan sumber daya dan manajemen pegawai. Keberadaan aparatur yang berkualitas akan sangat ditentukan oleh kemampuan aparatur yang bersangkutan untuk mengimplementasikan prinsip-prinsip good governance dalam penyelenggaraan pemerintahan dan pelayanan publik mulai dari tingkat kota, kecamatan, sampai kelurahan.

Kinerja aparatur merupakan suatu hasil kerja aparatur bersangkutan dalam melaksanakan tugasnya sesuai dengan tanggung jawab yang telah diberikan pada waktu tertentu. Kinerja aparatur dapat diukur melalui tiga dimensi, yaitu (Dharma, 2003):

1. Kuantitas kerja (quantity of work), yaitu kemampuan aparatur dalam menyelesaikan pekerjaan berdasarkan volume/jumlah yang harus diselesaikan atau dicapai, dengan indikator tidak menunda pekerjaan yang diberikan, pekerjaan yang diberikan sesuai dengan tugas pokok yang ditentukan, dan membandingkan hasil pekerjaan aparatur dengan program kerja yang telah ditentukan.

2. Kualitas kerja (quality of work), yaitu kemampuan aparatur dalam menyelesaikan pekerjaan berdasarkan baik buruknya pekerjaan yang harus diselesaikan, dengan indikator kemampuan aparatur dalam memeriksa kembali pekerjaan yang telah diselesaikan, akurasi dalam penyelesaian pekerjaan, kemampuan menyelesaikan tugas sesuai standar kerja, kemampuan mencapai target pekerjaan

3. Ketepatan waktu (timeliness), yaitu melalui kemampuan aparatur dalam menyelesaikan pekerjaan berdasarkan waktu yang telah ditentukan, dengan indikator kemampuan aparatur yang berkaitan dengan efektivitas dan efisiensi pekerjaan.

Dalam kaitannya dengan implementasi e-Government, maka muncul suatu pertanyaan tentang mampukah $e$ Government memunculkan perbedaan atau berpengaruh terhadap kinerja aparatur pemerintah?

\section{METODE PENELITIAN}

Kajian tentang peningkatan kinerja aparatur melalui $e$-Government ini dilakukan dengan menggunakan metode penelitian deskriptif kualitatif. Penelitian deskriptif merupakan penelitian yang bertujuan untuk memberikan atau menjabarkan suatu keadaan atau fenomena yang terjadi saat ini dengan menggunakan prosedur ilmiah untuk menjawab masalah secara aktual (Sugiyono, 2017:6).

Penelitian kualitatif menghendaki pelaksanaan penelitian berdasarkan pada 
situasi wajar (natural setting) sehingga kerap disebut sebagai metode naturalistik.

Beberapa ciri penelitian kualitatif antara lain adalah bersifat alamiah, bersifat deskriptif, sasaran penelitian berlaku sebagai subjek penelitian (informan), analisis data dilakukan secara induktif (Idrus, 2016:2324). Analisis induktif berpijak pada faktafakta yang bersifat khusus, kemudian diteliti dan akhirnya menemukan pemecahan persoalan yang bersifat umum. Induktif merupakan cara berpikir untuk menarik suatu simpulan umum dari berbagai kasus yang bersifat individual (Mardalis, 2014:21). Data-data sebagai bahan analisis dikumpulkan melalui teknik desk research dan dianalisis secara kualitatif.

\section{HASIL DAN PEMBAHASAN}

Kajian ini akan menyoroti adanya perbedaan kondisi kinerja aparatur pada 2 (dua) lembaga pada pemerintah daerah sehubungan dengan implementasi $e$ Government, yaitu aparatur pada Pemerintah Kota Cimahi (hasil penelitian

Dewi Kurniasih, Tatik Fidowaty, dan Poni Sukaesih, 2012) serta pada Badan

Pengelolaan Keuangan dan Aset Daerah Kabupaten Tanggamus (hasil penelitian

Reza Handika, 2017). Aspek kajian kedua penelitian tersebut sama-sama mengukur kinerja aparatur pemerintah daerah pasca implementasi e-Government.

Sebagaimana telah dikemukakan bahwa implementasi $e$-Government mencakup salah satunya aplikasi Government to Employees.

Aplikasi tersebut digunakan antara lain untuk menilai pelaksanaan tugas-tugas aparatur sehingga akan terwujud aparatur yang berkinerja tinggi. Wujud dari implementasi e-Government sehubungan dengan kinerja aparatur adalah e-kinerja (digunakan untuk pembuatan SKP bulanan dan tahunan serta penilaian pegawai, yang berhubungan dengan target, realisasi, dan prestasi kerja), SISDM (sistem informasi untuk mengelola data pegawai), e-presensi (aplikasi untuk pengelolaan data presensi pegawai), SILK (layananan untuk kepegawaian, izin belajar dan kenaikan gaji berkala, dan izin cuti online) dan TPP. Saat ini pemerintah berinovasi untuk meningkatkan kualitas aparatur agar lebih baik. Dengan inovasi tersebut pemerintah berharap kinerja aparatur akan lebih meningkat dan pada gilirannya akan meningkatkan kepercayaan masyarakat.

Dalam penelitian Kurniasih dkk., dikaji pengaruh implementasi e-Government terhadap kinerja aparatur, sedangkan penelitian Handika menganalisis perbedaan kinerja aparatur sebelum dan sesudah implementasi e-Government. Adapun Dimensidimensi kinerja yang diukur meliputi:

1. Dimensi kinerja yang dikaji dalam penelitian Kurniasih dkk. meliputi kualitas kerja, kuantitas kerja, ketepatan waktu, efektivitas biaya, kebutuhan pengawasan, dan pengaruh interpersonal.

2. Dimensi kinerja yang dikaji dalam penelitian Handika meliputi kualitas kerja, kuantitas kerja, dan ketepatan waktu.

Berdasarkan hasil penelitian Handika, diketahui beberapa hal menyangkut kinerja aparatur dalam kaitannya dengan implementasi $e$-Government sebagai berikut.

1. Terdapat perbedaan signifikan pada kuantitas kerja sebelum penerapan $e$ Government dengan sesudah implementasi e-Government.

2. Kualitas kerja menjadi variabel yang tidak memperlihatkan perbedaan signifikan pada kinerja sesudah implementasi e-Government.

3. Terdapat perbedaan signifikan pada variabel ketepatan waktu sebelum dengan setelah implementasi $e$ Government. 
Hasil penelitian di atas menunjukkan bahwa implementasi e-Government secara umum telah memberikan pengaruh yang positif terhadap kinerja aparatur, khusus pada dimensi kuantitas kerja dan ketepatan waktu. Di sisi lain, implementasi $e$ Government tidak secara sertamerta mampu meningkatkan kualitas kerja aparatur. Hal itu menandakan masih perlunya upaya-upaya untuk meningkatkan kualitas kerja aparatur sehingga implementasi e-Government dapat berlangsung serta memberikan hasil yang lebih optimal.

Sama halnya dengan penelitian Handika, kajian yang dilakukan oleh Kurniasih dkk. juga menghasilkan kenyataan tentang adanya pengaruh dari implementasi $e$ Government terhadap kinerja aparatur. Menurut penelitian Kurniasih dkk. terhadap aparatur di lingkungan Pemerintah Kota

Cimahi, diketahui bahwa implementasi $e$ Government memberikan pengaruh sebesar 54,85 persen terhadap perubahan kinerja aparatur. Dengan demikian, implementasi $e$ Government merupakan salah satu faktor yang dominan dalam menentukan perubahan kinerja aparatur pemerintah di Kota Cimahi.

Penelitian Kurniasih dkk. menunjukkan kondisi kinerja aparatur pasca implementasi e-Government sebagai berikut.

1. Kualitas kerja aparatur cukup tinggi dilihat dari kesesuaian antara kegiatan dan tujuan yang ditetapkan. Kualitas pemerintahan dan pelayanan tidak mungkin meningkat tanpa adanya usaha-usaha yang nyata sehingga perlu adanya kesesuaian antara kegiatankegiatan, proses, dan hasil kerja dengan tujuan yang telah ditetapkan.

2. Kuantitas kerja aparatur cukup tinggi dilihat dari beban kerja dan besaran hasil. Setiap aparatur sudah mempunyai job description masing-masing. Beban kerja yang dipangku oleh setiap aparatur serta hasilnya sudah cukup sesuai dengan tujuan yang telah ditargetkan.
3. Dalam hal ketepatan waktu, terlihat bahwa aparatur dapat menyelesaikan tugas-tugasnya secara cukup tepat waktu.

Masih sejalan dengan hasil penelitian Handika, penelitian Kurniasih dkk. juga merekomendasikan perlunya upaya peningkatan kualitas aparatur yang antara lain dapat dilakukan melalui pelatihan dan pembinaan aparatur secara terus-menerus sehingga pelaksanaan e-Government menjadi lebih baik. Hal ini berkaitan dengan hasil kajian, baik penelitian Handika maupun

Kurniasih dkk., yang juga menemukan kenyataan mengenai masih kurangnya

SDM aparatur yang kompeten. Dengan diimplementasikannya e-Government maka hampir semua kegiatan pemerintahan menggunakan secara elektronik, mulai dari pelayanan pengaduan, dan pemberian informasi, bahkan pelayanan untuk pegawai pemerintahnya sendiri. Namun demikian, belum semua aparatur pemerintah mengerti dan bisa untuk menjalankannya, sehingga ketika sewaktu-waktu ada pergantian tugas atau mutasi harus selalu diberikan pengarahan setiap ada pergantian pegawai karena kurangnya pengetahuan mengenai TI

(Teknologi Informasi). Oleh karena itu perlu dilakukan berbagai upaya pengembangan SDM.

Dalam rangka pengembangan SDM guna mendukung implementasi e-Government, Instruksi Presiden Nomor 3 Tahun 2003 telah menetapkan beberapa instrumen, yaitu sebagai berikut.

1. Meningkatkan kesadaran dan pemahaman tentang pentingnya informasi serta pendayagunaan teknologi informasi dan komunikasi $(e-$ literacy), baik di kalangan pemerintah dan pemerintah daerah otonom maupun di kalangan masyarakat dalam rangka mengembangkan budaya informasi ke arah terwujudnya masyarakat informasi (information society). 
2. Pemanfaatan sumber daya pendidikan dan pelatihan termasuk perangkat teknologi informasi dan komunikasi secara sinergis, baik yang dimiliki oleh lembaga pemerintah maupun nonpemerintah/masyarakat.

3. Pengembangan pedoman penyelenggaraan pendidikan dan pelatihan bagi lembaga pemerintah agar hasil pendidikan dan pelatihan tersebut sesuai dengan kebutuhan pengembangan dan pelaksanaan $e$ Government.

4. Penyelenggaraan pendidikan dan pelatihan teknologi informasi dan komunikasi bagi aparat pelaksana yang menangani kegiatan bidang informasi dan komunikasi dan aparatur yang bertugas dalam memberikan pelayanan publik, maupun pimpinan unit/lembaga, serta fasilitas pendidikan dan pelatihan bagi calon pendidik dan pelatih maupun tenaga potensial di bidang teknologi informasi dan komunikasi yang diharapkan dapat mentransfer pengetahuan/keterampilan yang dimiliki kepada masyarakat di lingkungannya.

5. Peningkatan kapasitas penyelenggaraan pendidikan dan pelatihan jarak jauh (distance learning) dengan memanfaatkan teknologi informasi dan komunikasi secara optimal untuk pemerataan atau mengurangi kesenjangan SDM di bidang teknologi informasi dan komunikasi antardaerah.

6. Perubahan pola pikir, sikap dan budaya kerja aparat pemerintah yang mendukung pelaksanaan e-Government melalui sosialisasi/penjelasan mengenai konsep dan program e-Government, serta contoh keberhasilan (best practice) pelaksanaan $e$-Government.

7. Peningkatan motivasi melalui pemberian penghargaan/apresiasi kepada seluruh SDM bidang informasi dan komunikasi di pemerintahan serta masyarakat yang secara aktif mengembangkan inovasi menjadi karya yang bermanfaat bagi pengembangan dan pelaksanaan $e$-Government.

\section{SIMPULAN}

Perkembangan teknologi di era globalisasi merupakan sebuah keniscayaan yang harus dihadapi sekaligus harus dimanfaatkan, termasuk pula kemajuan teknologi informasi dan komunikasi yang demikian pesat.

Salah satu bentuk pemanfaatan teknologi informasi dan komunikasi tersebut guna mendukung terwujudnya good government dan good governance adalah dengan mengimplementasikan e-Government yang telah ditetapkan oleh pemerintah melalui Instruksi Presiden Nomor 3 Tahun

2003. Selain dapat mendukung upayaupaya menciptakan pelayanan publik yang optimal, implementasi e-Government juga dapat menjadi instrumen utama dalam keberhasilan reformasi birokrasi. Ada harapan besar implementasi e-Government dapat meningkatkan kinerja aparatur pemerintahan. Berdasarkan hasil dari beberapa penelitian diketahui bahwa implementasi e-Government nyata-nyata berpengaruh terhadap kinerja aparatur, khususnya dalam dimensi kuantitas kerja dan ketepatan waktu. Dimensi kinerja yang kurang terasa terpengaruhi oleh adanya implementasi e-Government adalah dimensi kualitas kerja. Hal ini menandakan bahwa belum semua aparatur mempunyai kompetensi yang merata dalam penguasaan teknologi informasi dan komunikasi yang merupakan instrumen utama implementasi e-Government. Kenyataan tersebut perlu menjadi bahan pemikiran untuk diadakannya pengembangan kualitas aparatur di bidang teknologi informasi dan komunikasi, yang dilaksanakan antara lain melalui peningkatan kesadaran dan pemahaman tentang pentingnya 
pendayagunaan teknologi informasi dan komunikasi dalam tata pemerintahan, pendidikan dan pelatihan yang kontinyu dan berkesinambungan, serta pengubahan pola pikir dan budaya dalam pemanfaatan teknologi.

\section{DAFTAR PUSTAKA}

Azis, Herry Abdul. 2008. Integrasi e-Government: Tantangan, Kebijakan dan Implementasi. Jakarta: Seminar Pelayanan Publik dan eGovernment, Bappenas.

Darsono dan Siswandoko, Tjatjuk. 2011. Sumber Daya Manusia Abad 21. Jakarta: Nusantara Consulting.

Dharma, Surya. 2003. Manajemen Kinerja Falsafah Teori dan Penerapannya. Yogyakarta: Pustaka Pelajar.

Fransiska Faskalia Viliyanti Eka, Djumadi, Enos Paselle. 2014. "Pengembangan Sumber Daya Manusia dalam Penerapan e-Government di Lingkungan Sekretariat Daerah Kabupaten Kutai Barat". e-Journal Administrative Reform, 2014, 2 (3): 20062018.

Handika, Reza. 2017. Kinerja Pegawai Sebelum dan Sesudah Berbasis e-Government. Tesis pada Program Pascasarjana Magister Ilmu Administrasi Fakultas Ilmu Sosial dan Ilmu Politik Universitas Lampung.

Idrus, Muhammad. 2016. Metode Penelitian Ilmu Sosial Pendekatan Kualitatif dan Kuantitatif. Jakarta: Erlangga.

Indrajit, Richardus Eko. 2005. e-Government in Action. Yogyakarta: Andi Offset.

Instruksi Presiden Nomor 3 Tahun 2003 tentang Kebijakan dan Strategi Nasional Pengembangan $e$ Government.

Irawan, Bambang. 2013. Studi Analisis Konsep eGovernment: Sebuah Paradigma Baru dalam Pelayanan Publik. Jurnal
Paradigma, Vol. 2 No.1, April 2013: 174201.

Kurniasih, Dewi, Tatik Fidowaty, dan Poni Sukaesih. 2013. Pengaruh Implementasi Kebijakan e-Government terhadap Kinerja Aparatur Kota Cimahi. Sosiohumaniora, Vol. 15, No. 1, Maret 2013: 6 -14.

Mardalis. 2014. Metode Penelitian Suatu Pendekatan Proposal. Jakarta: Bumi Aksara.

Sedarmayanti. 2009. Sumber Daya Manusia dan Produktivitas Kerja. Bandung: CV. Mandar Maju.

Sugiyono. 2014. Memahami Penelitian Kualitatif. Bandung: Alfabeta.

2017. Metode Penelitian Kuantitatif, Kualitatif dan R \& D. Bandung: Alfabeta. 